\title{
Development of the External Genitalia in Rat Fetuses
}

\author{
Tomoo INOMATA, Yasunobu EGUCHI* \\ and Tsunenori NAKAMURA \\ Department of Laboratory Animal Science and *Department of \\ Anatomy II, Azabu University School of Veterinary \\ Medicine, Fuchinobe, Sagamihara, \\ Kanagawa 229, Japan
}

(Received 22 March 1985 / Accepted 21 May 1985)

\begin{abstract}
Development of the external genitalia in rat fetuses was studied with special reference to the formation of the labia pudenda and the determination of the stage at which the sex difference could be recognized from changes in the external structures. The urogenital fold located on either side of the urogenital groove gradually enlarges and begins to enclose the genital tubercle with its counter fold on day 20 of gestation. Thus, the urogenital folds, which are known to become the labia minora and the prepuce of clitoris in the human, are differentiated only into the prepuce of clitoris in the rat. The genital swellings situated caudally to the urogenital folds are not well developed and come to be inconspicuously flat in situ at the end of gestation. However, the labia majora are formed by the time of puberty when the vagina opens. Therefore, it seems that the genital swellings contribute to the formation of the labia majora after birth. Sex difference in development of the external genitalia is recognized on day 17 of gestation; a small oval urogenital orifice is larger in male than in female and the genital swellings are better developed in male than in female.
\end{abstract}

The external genitalia of either sex are diversely differentiated from a common starting point. In early stage, the elements of the external genitalia are developed on the caudoventral surface of the abdominal wall as vaguely outlined elevations known as the genital tubercle, the genital swellings and the urogenital folds. In the male, the genital tubercle becomes markedly elongated to form the glans penis, the urogenital folds enclose the penis as the prepuse, and the genital swellings become enlarged to form the scrotum. These findings are the same in many domestic animals $[1,2,5,7]$. In the female, the genital tubercle becomes the clitoris. However, the development of the external genitalia, particularly in the formation of the labia pudenda, seems somewhat different in animal species. For example, in the human and pig, the urogenital folds become the labia minora and the genital swellings develop into the labia majora $[5$, 7]. In contrast, in cattle [2], the labia pudenda are originated only from the urogenital folds and the genital swellings disappear.

The present study was undertaken to know the way of formation of the labia pudenda in rat fetuses and also to clarify the starting period of the sexual differentiation of the external genitalia.

\section{Materials and Methods}

Wistar rats were used in this study. 
They were given a commercial diet (Funabashi MM-1) and water both $a d$ libitum. Females were kept with males overnight and the presence of sperm in the vaginal smear was examined in the following morning, the time when was counted as day 0 of gestation. Fetuses were obtained from mothers on days 15 to 21 of gestation. Fetuses on days 15 and 17 were fixed in toto in Bouin's fluid. On and after day 18, upper half of the body of each fetus was cut away and the lower half of the body was put into Bouin's fluid. The sex of each fetus on and after day 17 was determined by the histological examination of their gonads. The sex on and after day 18 was easily distinguished by the appearance of external genitalia; the anogenital distance was longer in male than in female.

\section{Results}

Day 15 of gestation: In the midline between the umbilical cord and the tail, there was a cone-like genital tubercle forwarding cephalad. The genital tubercle had an undercut groove on its ventral surface. The urogenital fold was situated on either side of this groove. Somewhat caudally to the lateral side of each genital fold, there was a vaguely outlined elevation known as the genital swelling (Fig. 1).

Day 16 of gestation: The genital swelling on either side approached the midline between the urogenital folds and the anus. The genital tubercle and urogenital folds were almost the same in situation as above. Either sex of fetuses was still not distinguishable from the outer view of the external genitalia (Fig. 2).

Day 17 of gestation: The genital tubercle turned to be spherical. The both genital swellings as well as the both urogenital folds were fused with each other in the midline just caudally to the genital tubercle. At this stage, the sex difference was noted from the outer view of the external genitalia; a small oval opening of the urogenital orifice appeared in the midline between the urogenital folds and the genital swellings, seemingly larger in male than in female. The male genital swellings were enlarged with the increase in the anogenital distance, but the female ones were little developed (Figs. 3 and 4 ).

Day 18 of gestation: Sex difference became clearer at this stage. In male, the genital swellings were more elevated, making the small urogenital orifice stretched longitudinally as the urethral groove. In contrast, in female, the urogenital orifice remained small in situ until the end of gestation (Figs. 5 and 6).

Day 19 of gestation: The genital tubercle rose up in both sexes. The urogenital folds gradually ensheathed the genital tubercle. The urethral groove in male observed clearly in this stage (Figs. 7 and 8).

Days 20 and 21 of gestation: The greater part of the genital tubercle, excepting its tip, was surrounded by the urogenital folds in both sexes. The urogenital folds were destined to be the penile prepuce in male and the clitoris prepuce in female. The genital swellings were clearly elevated in male, but obscurely flattened in female. At this stage, the urethral groove in male became unclear (Figs. 9 and 10).

\section{Discussion}

Previous studies $[1,2,5,7]$ have shown that the labia pudenda are completely established during the fetal life in many domestic animals. However, the labia pudenda are not established in rat fetuses. The present study showed that in the rat the urogenital folds were differentiated into the prepuce of clitoris and that the genital swellings became obscurely flat, before birth.

In the human, Spaulding [7] pointed out that the genital swellings became the labia majora and that the urogenital folds 
were differentiated into the labia minora and the prepuce of clitoris. In the cattle, Inomata et al. [2] described that the genital swellings in female moved craniad beyond the genital tubercle to disappear an early fetal stage and that the labia pudenda were originated only from the urogenital folds. In the dog, Christensen [1] stated that the genital swellings became the labia pudenda, although the destination of the urogenital folds was not clear.

Selye [6] showed that the treatment with testosterone did not induce full scrotal development in castrated immature rats, unless the scrotum was mechanically distended by an artificial glass testis. From this result, Selye concluded that the normal development of the scrotum required both the mechanical effects of testis and the hormonal effects of testosterone. As reckoned from the fact that the female genital swellings do not receive such distending effects, Selye's opinion seems to be pertinent for justifying the fact that the female genital swellings turn to be flat and obscure. Nevertheless, the labia pudenda develop at puberty. This is very difficult to explain, but at any rate, the genital swellings may be interpreted to contribute to the formation of the labia after birth.
Sex difference of the external genitalia was first recognized on day 17 of gestation, when a small oval urogenital orifice appeared in the midline between the urogenital folds and genital swellings, apparently larger in male than in female. Also, the genital swellings were well developed in male with the increase in the anogenital distance. These observations are well in line with those by Moreau [4] and Jost [3].

\section{References}

[1] Christensen, G. C. (1979). Embryology of the urogenital system. In Miller's Anatomy of the Dog, pp. 595-598. Evans, H. E., and Christensen, G. C. (edit)., W. B. Saunders, Philadelphia.

[2] Inomata, T., Eguchi, Y., Yamamoto, M., Asari, M., Kano, Y., and Mochizuki, K. (1982). Development of the external genitalia in bovine fetuses. Jpn. J. Vet. Sci., 44, 489-496.

[3] Jost, A. (1967). Modalities in the action of androgens of the foetus. Research on Steroids, 3. 207220.

[4] Moreau P. M.-G. (1962). Évolution de la distance anogénitale chez le foetus de rat, en fonction de l'age, du poids et du sexe. Arch. Anat. Micr. Morphol. Exp., 51, 95-106.

[5] Patten, B. M. (1948). The external genitalia. In Embryology of the Pig, pp. 224-226, Patten B. M. (edit.), McGraw-Hill, New York.

[6] Selye, H. (1943). Factors influencing development of scrotum. Anat. Rec., 85, 377-385.

[7] Spaulding, M. M. (1921). The development of the external genitalia in the human embryo. Contrib. Embryol., 61, 67-88.

\section{ラット外生殖器の発達について}

猪股智夫·江口保啺*.中村経紀

麻布大学獣医学部実験動物学講座

* 麻布大学獣医学部家畜解剖学第二講座

ラット胎仔の外生殖器の発達, 特に陰唇の形成と外生 殖器の性分化の時期について観察した。陰唇の形成につ いて—尿生殖ヒダ, すなわち, ヒトでいう陰核包皮と 小陰唇となるものは, 胎龄20日目の時期に, 生殖結節を ほとんど覆うように発達して陰核包皮となった。生殖隆
起, すなわち，ヒトでいう大陰唇となるものは，胎生末 期までにそのままの位置で平担，かつ不明瞭となった。 すなわち, 胎生期のラットには, ヒトに相当するような 陰唇は認められなかった。しかし，陰唇は腔開口時に形 成される。このことを考えると, 生殖隆起は, 出生後の 
陰居を形成するものと思われた。外生殖器の性分化につ いて一一胎㱓の17日目に㧊いて, 雌雄ともに尿生殖ヒダ と生殖隆起との間に棈円形の小さな尿生殖口が認められ た。この尿生殖口は, 雄のほうが倠よりも大きかった。
生殖隆起も，雄のほうが良く発達していた。また，これ に一致して, 肛門と尿生殖口との間の距離は, 雄のほう が雃よりも長かった。すなわち, ラット胎仔の外生殖器 に性分化が認められる時期は，胎齢の17日目であった。

\section{Explanation of Figuers}

1: Anus, 2: Genital swelling, $3:$ Genital tubercle, $4:$ Penile prepuce (male) and Clitoris prepuce (female), 5: Tail, 6: Umbilical cord, $7:$ Urethral groove, $8:$ Urogenital fold, 9: Urogenital groove, 10: Urogenital orifice.

Fig. 1. A fetus on day 15 of gestation (the sex cannot be determined from the outer view). In the midline between the umbilical cord (6) and the tail (5), there is a cone-like genital tubercle (3) forwarding cephalad. The genital tubercle has an urogenital groove (9) on its ventral surface. The urogenital fold (8) is situated on either side of this groove. Somewhat caudally to the lateral side of each genital fold, there is a vaguely outlined elevation known as the genital swelling (2). $\times 4.5$

Fig. 2. A fetus on day 16 of gestation (the sex cannot be determined from the outer view). The genital swelling (2) on either side approaches the midline between the urogenital folds ( 8 ) and the anus (1). The genital tubercle (3) and urogenital folds are almost the same in situation as in Fig. $1 . \times 4.5$

Fig. 3. A male fetus on day 17 of gestation. The genital tubercle (3) turns to be spherical. The both genital swellings (2) as well as the both urogenital folds (8) are fused with each other in the midline between the genital tubercle and the anus (1). A small oval opening of the urogenital orifice (10) appears in the midline between the urogenital folds and the genital swellings. The genital swellings are enlarged with the increase in the anogenital distance. Sex differenceis observable in this stage from the outer view. $\times 4.5$

Fig. 4. A female fetus on day 17 of gestation. The urogenital orifice (10) was smaller than that of male (Fig. 3). The genital swellings $(2)$ are little developed. $\times 4.5$

Fig. 5. A male fetus on day 18 of gestation. The genital swellings (2) are well elevated, making the small urogenital orifice stretched longitudinally as the urethral groove (7). $\times 4.5$

Fig. 6. A female fetus on day 18 of gestation. Each element of the external genitalia is not well developed as compared with that of male (Fig. 5). The urogenital orifice (10) remains to be small in situ until the end of gestation. $\times 4.5$

Fig. 7. A male fetus on day 19 of gestation. The genital tubercle (3) rises up. The urogenital folds (8) gradually ensheath the genital tubercle. The urethral groove (7) becomes clearer. $\times 4.5$

Fig. 8. A female fetus on day 19 of gestation. The genital tubercle (3) rises up. The urogenital folds (8) gradually ensheath the genital tubercle as in male (Fig. 7). $\times 4.5$

Fig. 9. A male fetus on day 20 of gestation. The greater part of the genital tubercle (3), excepting its tip, is surrounded by the urogenital folds (8) which are destined to be the penile prepuce (4). The genital swellings (2) are clearly elevated. The urethral groove becomes unclear. $\times 4.5$

Fig. 10. A female fetus on day 20 of gestation. The urogenital folds surround the genital tubercle (3) as in male (Fig. 9). The urogenital folds are destined to be the clitoris prepuce (4). The genital swellings are obscurely flattened. $\times 4.5$ 

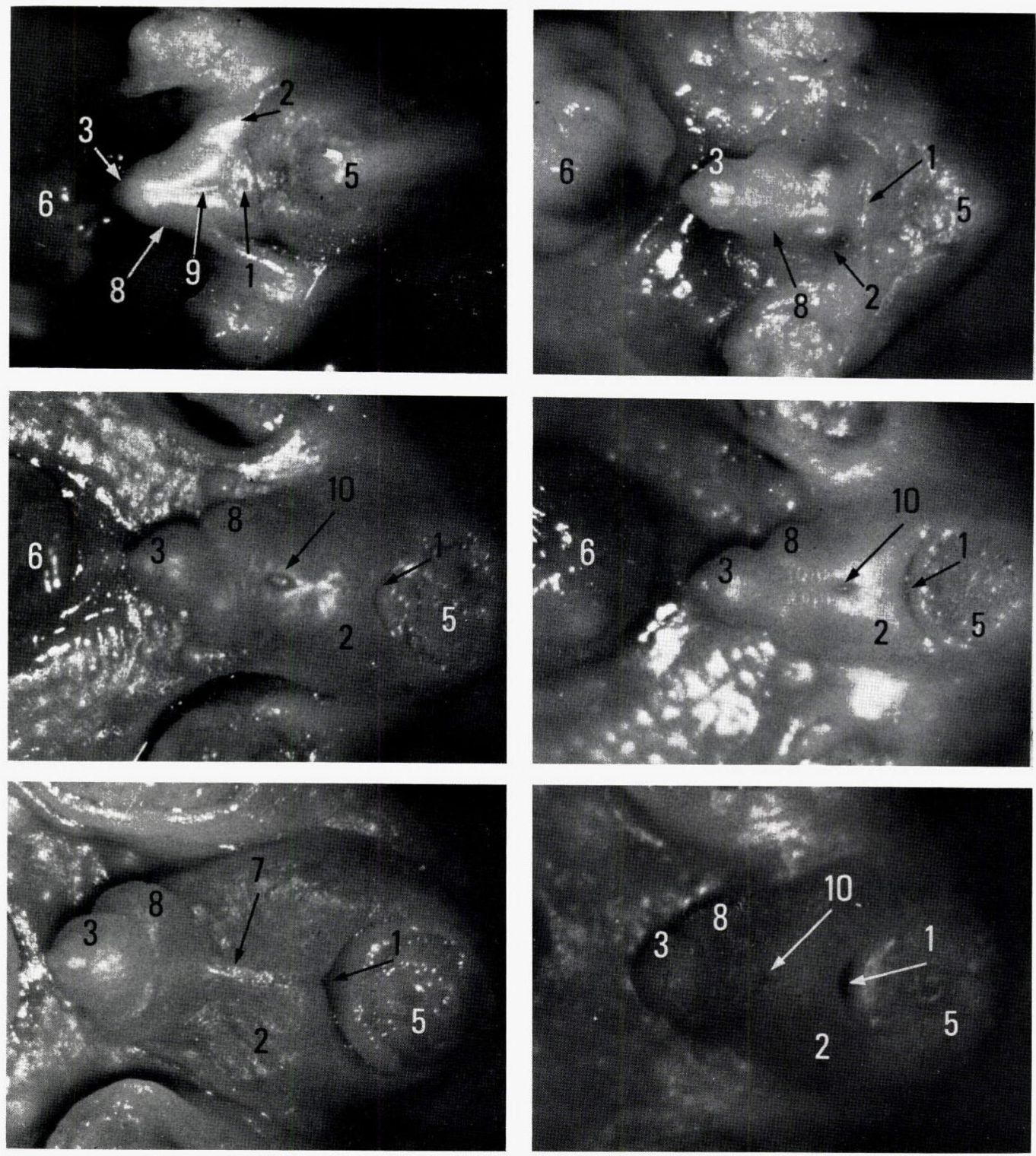

\begin{tabular}{l|l} 
Fig. 1 & Fig. 2 \\
\hline Fig. 3 & Fig. 4 \\
Fig. 5 & Fig. 6
\end{tabular} 

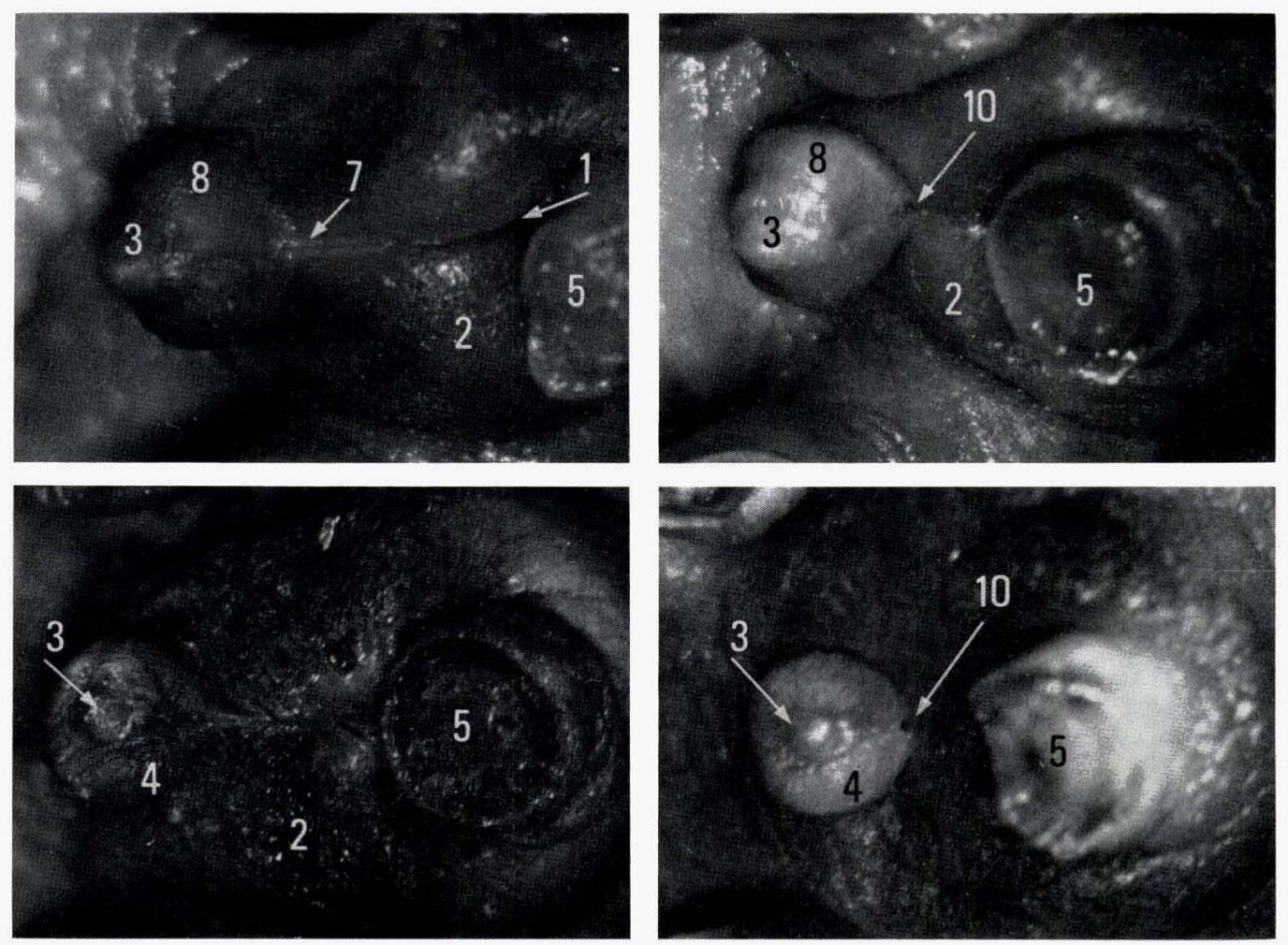

\begin{tabular}{l|l} 
Fig. 7 & Fig. 8
\end{tabular}

\begin{tabular}{l|l} 
Fig. 9 & Fig. 10
\end{tabular} 